\title{
EVALUATION OF MECHANICAL WEED MANAGEMENT TECHNIQUES ON WEED AND CROP POPULATIONS
}

\author{
S.J. REDDIEX ${ }^{1}$, S.D. WRATTEN ${ }^{1}$, G.D. HILL ${ }^{1}$, G.W. BOURDÔT ${ }^{2}$ and \\ C.M. FRAMPTON ${ }^{3}$
}

\author{
${ }^{1}$ Soil, Plant and Ecological Sciences Division, PO Box 84, Lincoln University \\ ${ }^{2}$ AgResearch, PO Box 60, Lincoln \\ ${ }^{3}$ Applied Management and Computing Division, PO Box 84, Lincoln University \\ Corresponding author: reddies1@lincoln.ac.nz
}

\begin{abstract}
One of the main barriers for conventional farmers converting to organic production is weed control. An experiment was set up to evaluate the efficacy of three mechanical weed control methods, tine weeder, spoon weeder and inter-row hoe (only in the beans (Phaseolus vulgaris)), in four organically grown crops. In borage (Borago officinalis), weed dry matter (DM) was reduced by $41 \%$ in tine-weeded plots but there was no treatment effect on crop DM or yield. There was no treatment effect in the peas (Pisum sativum). In linseed (Linum usitatissimum), mechanical weeding reduced weed DM by $41 \%$ and resulted in a $28 \%$ increase in crop yield. In beans, weed DM was reduced by $74 \%$ in mechanicallyweeded plots but the tine weeder reduced crop DM compared with the other mechanical weeding treatments.

Keywords: organic agriculture, mechanical weed control, borage, linseed, process peas, dwarf French beans.
\end{abstract}

\section{INTRODUCTION}

Despite premiums for organic produce, commercial farmers in New Zealand are reluctant to convert to organic production. One of the key impediments is weed management (Snowdon \& Wratten 2000). Organic farmers use a range of methods to manage weeds, including seed-bed preparation, crop planting density, crop variety, crop rotation and mechanical weed control (Lee 1995). In New Zealand, there has been little research on weed management in organic systems. Internationally, research on mechanical weed control is also limited, with most research being focused on finding an integrated approach of mechanical weed control and the use of lower rates of herbicides. In the United Kingdom, Pullen \& Cowell (1997) compared the ability of six mechanical weeding methods to control weeds. Of these weeding methods the harrow was found to be the least effective at controlling weeds, the rotary hoe was not as effective against established plants and the sweep was more effective when the weeds were more established (five true leaves). Also in the United Kingdom, Welsh et al. (1997) found the ability of the tine weeder to control weeds in wheat (Triticum aestivum) depended on the timing of use and the weed species present, whereas control by the inter-row hoe was relatively independent of time and weed species.

The work described here aimed to compare the relative efficacy of the tine weeder, spoon weeder and inter-row hoe in four organically grown crops (borage, linseed, peas and beans) under New Zealand conditions. These three mechanical methods are considered to be representative of what might be commonly used in 'broadacre' organic production. It was anticipated that the three methods would vary in their efficacy due to their contrasting modes of action. The tine weeder scratches over the soil surface whereas the spoon weeder has a surface shattering action (spokes enter the soil vertically and exit at an angle), but both control intra- and inter-row weeds (Bowman 1997). The 
inter-row hoe cuts off plant roots just below the soil surface and controls only inter-row weeds (Pullen \& Cowell 1997). This work also allows a comparison between the effect of mechanical weeding in crops of different growth habit. Less competitive crops (beans and linseed) are likely to benefit more from weeding than competitive crops (peas and borage).

\section{METHODS}

An experiment was established during 1999-2000 at 'Kowhai Farm', the Heinz Wattie's organic farm at Lincoln University. The trial was a randomised complete block design with four treatments and five replicates. The trial was carried out in each of the four commercial crops grown at Kowhai Farm. Three mechanical weeding treatments (Lely tine weeder, John Deere spoon weeder and Farmall Super A with custom built mid and rear mounted inter-row hoes) were compared with control plots which were not weeded during the crop growing season. The four spring-sown crops were borage (Borago officinalis, unnamed cultivar) and process peas (Pisum sativum cv. Bounty) as good competitors, and linseed (Linum usitatissimum cv. Hinau) and dwarf French beans (Phaseolus vulgaris cv. Labrador) as poor competitors. The inter-row hoe was used only in the bean crop because row spacing was too narrow in the other crops $(17.5 \mathrm{~cm}$ compared with $37.5 \mathrm{~cm}$ in the beans). Treated plots were $12 \mathrm{~m}$ wide (two passes of the weeding implement) and $20 \mathrm{~m}$ long; control plots were $6 \mathrm{~m}$ wide and $20 \mathrm{~m}$ long. Mechanical weeding was done at 28 days after sowing (DAS) in the borage, 37 DAS in the linseed, 21 DAS in the peas and 23 and 48 DAS in the beans.

Measurements were made of weed and crop dry matter (DM) production at mid season and final harvest. Crop yield was measured at the time of commercial harvest. For midseason sampling, weed and crop DM were measured from two $0.25 \mathrm{~m}^{2}$ quadrats/plot. At final harvest, four $0.25 \mathrm{~m}^{2}$ quadrats/plot were taken to measure weed and crop DM and crop yield.

The data were analysed using the SYSTAT statistical software package with each crop analysed separately. Repeated measures ANOVA was used to analyse weed and crop DM. If the time $\mathrm{x}$ treatment interaction was not significant $(\mathrm{P}>0.05)$, then the two sampling dates were averaged, to compare treatments. Crop yield data were analysed using ANOVA. When significant treatment effects were indicated by ANOVA, pairwise comparisons of treatments were conducted using Fishers LSD test.

\section{RESULTS}

Borage

Weed DM was reduced by $41 \%$ in the tine-weeded plots compared with the mean of the control and spoon-weeded plots $(\mathrm{P}<0.05)($ Table 1). Spoon-weeded and control plots were not significantly different in weed DM $(\mathrm{P}>0.05)$. There was no effect of mechanical weeding treatment on either crop DM or crop yield $(\mathrm{P}>0.05)$.

Peas

There was no effect of mechanical weeding treatment on weed DM, crop DM or crop yield $(\mathrm{P}>0.05)$ (Table 1) Linseed

Weed DM was reduced by $41 \%$ in mechanically-weeded plots compared with the control plots $(\mathrm{P}<0.05)$ (Table 1). There was no significant difference in weed DM between mechanically-weeded plots $(\mathrm{P}>0.05)$. There was also no significant effect of treatment on mid-season crop DM (P>0.05). At harvest there was no significant difference between the spoon- and tine-weeded plots for crop DM $(\mathrm{P}>0.05)$ but control plots had $17 \%$ less crop DM than the mean of mechanically-weeded plots $(\mathrm{P}<0.05)$. Yield was reduced by $22 \%$ in control plots compared with the mean of the mechanically-weeded plots $(\mathrm{P}<0.05)$. Beans

Weed DM was reduced by $74 \%$ in mechanically-weeded plots compared with the control plots $(\mathrm{P}<0.05)$, but there were no significant differences between the mechanically- 
TABLE 1: Effect of different mechanical weeding methods on weed dry matter $\left(\mathrm{g} \mathrm{DM} / \mathrm{m}^{2}\right)$, crop DM $\left(\mathrm{g} \mathrm{DM} / \mathrm{m}^{2}\right)$ and crop yield (t/ha, $10 \%$ moisture for borage and linseed; $t / h a$, fresh weight for peas and beans) in four organically grown crops. Results are the mean for the two sampling dates unless otherwise stated.

\begin{tabular}{|c|c|c|c|c|c|}
\hline & & Control & Tine & Spoon & Inter-row hoe \\
\hline \multicolumn{6}{|l|}{ Borage } \\
\hline Weed DM & & $45.3^{\mathrm{a} 1}$ & $27.7^{\mathrm{b}}$ & $48.0^{\mathrm{a}}$ & - \\
\hline Crop DM & & $598^{\mathrm{a}}$ & $595^{\mathrm{a}}$ & $574^{\mathrm{a}}$ & - \\
\hline Yield & & $0.68^{\mathrm{a}}$ & $0.71^{\mathrm{a}}$ & $0.58^{\mathrm{a}}$ & - \\
\hline \multicolumn{6}{|l|}{ Peas } \\
\hline Weed DM & & $9.29^{\mathrm{a}}$ & $8.13^{\mathrm{a}}$ & $10.0^{\mathrm{a}}$ & - \\
\hline Crop DM & & $521^{\mathrm{a}}$ & $596^{\mathrm{a}}$ & $509^{\mathrm{a}}$ & - \\
\hline Yield & & $11.3^{\mathrm{a}}$ & $10.1^{\mathrm{a}}$ & $12.4^{\mathrm{a}}$ & - \\
\hline \multicolumn{6}{|l|}{ Linseed } \\
\hline Weed DM & & $199^{\mathrm{a}}$ & $102^{\mathrm{b}}$ & $132^{\mathrm{b}}$ & - \\
\hline \multirow[t]{2}{*}{ Crop DM ${ }^{2}$} & 1. & $500^{\mathrm{a}}$ & $530^{\mathrm{a}}$ & $486^{\mathrm{a}}$ & - \\
\hline & 2. & $741^{\mathrm{b}}$ & $902^{\mathrm{a}}$ & $890^{\mathrm{a}}$ & \\
\hline Yield & & $3.18^{\mathrm{b}}$ & $4.11^{\mathrm{a}}$ & $4.03^{\mathrm{a}}$ & - \\
\hline \multicolumn{6}{|l|}{ Beans } \\
\hline Weed DM & & $181^{\mathrm{a}}$ & $34.2^{\mathrm{b}}$ & $68.4^{\mathrm{b}}$ & $39.6^{\mathrm{b}}$ \\
\hline Crop DM & & $85.0^{\mathrm{b}}$ & $107^{\mathrm{b}}$ & $151^{\mathrm{a}}$ & $156^{\mathrm{a}}$ \\
\hline Yield & & $6.30^{\mathrm{b}}$ & $8.36^{\mathrm{bc}}$ & $11.4^{\mathrm{ac}}$ & $11.6^{\mathrm{ac}}$ \\
\hline
\end{tabular}

${ }^{1}$ Values in a row with the same letter are not significantly different $(\mathrm{P}>0.05)$.

${ }^{2}$ Results are presented for both sampling dates since there was a significant time $\mathrm{x}$ treatment interaction; $1=$ mid-season, $2=$ harvest.

weeded plots $(\mathrm{P}>0.05)$ (Table 1). Crop DM was highest in hoe- and spoon-weeded plots and was $60 \%$ higher in these plots than in the control and tine-weeded plots $(\mathrm{P}<0.05)$. The control plots gave the lowest yield but this was not significantly different from tineweeded plots. $(\mathrm{P}>0.05)$. Yield was reduced by $45 \%$ in control plots compared with the mean of the hoe- and spoon-weeded plots $(\mathrm{P}<0.05)$. The hoe- and spoon-weeded plots gave the greatest yield but were not significantly different from tine-weeded plots $(\mathrm{P}>0.05)$.

\section{Borage}

\section{DISCUSSION}

Vigorous and tall growing crops are able to compete favourably with weeds (Muzik 1970). Borage is a tall, fast-growing crop with good ground cover and was therefore unaffected by the greater weed DM in the spoon-weeded and control plots. The fact that the spoon weeder did not reduce the weed population, but the tine weeder did, could possibly be attributed to the fact that the spoon weeder was used too late to be effective. The rotary hoe is not effective once the plant roots go deeper than the working depth of the rotary hoe (Regehr 1993). The greater weed DM in the spoon-weeded and unweeded plots (Table 1) may have resulted in more weed seed production and there may be a greater weed burden in these plots next season. This will be evaluated for two further field seasons.

Peas

The lack of a treatment effect for weed DM in peas could be a result of the very low weed population making it difficult to detect any changes with weeding. Additionally, peas may not be very sensitive to weed competition. For example, Stiefel \& Popay 
(1990) showed that when a weed population was reduced by as much as $66 \%$ with tine weeding, crop yield was not improved. This was attributed to the crop smothering the weeds, preventing them affecting crop growth. However, the possibility that damage to the crop by the tine weeder may have balanced the advantages of reducing the weed population was not discounted (Stiefel \& Popay 1990), and such an effect may also explain our results.

Linseed

Since linseed plants have a sparse growth habit and are not very efficient at using water for uptake of nutrients and plant growth, they are not strongly competitive with weeds (Gruenhagen \& Nalewaja 1969). The greater weed DM in control plots probably reduced both crop DM and crop yield by final harvest. In addition, previous research has shown weed interference reduces the oil content and iodine value of the oil (Friesen 1986).

Beans

Although all three mechanical weeders were equally effective in reducing weed DM, the tine weeder also reduced crop DM, compared with the spoon weeder and inter-row hoe. A similar result has been found in pinto beans (Phaseolus vulgaris), where tine weeding reduced the bean stand and caused crop injury but did not affect bean yield compared with the weed free control (Vangessel et al. 1995). In the same work, a rotary hoe gave comparable weed control but no crop damage. The rotary hoe has an additional advantage in that it improves soil aeration by breaking up soil crusts. In the present study, weed competition significantly reduced bean yield in control plots compared with hoe- and spoon-weeded plots.

These results are based on each mechanical weeder being used twice during the crop growing season. Field observations indicated that it was only after the second tine weeding that the crop stand was affected. This is probably because the plants were bigger at this stage and were more easily pulled out by the tines. Therefore for beans, tine weeding may be useful for managing weeds early in the season (it controls both intra- and inter-row weeds) but should be combined with inter-row hoeing later in the season when the bean plants are larger.

\section{Conclusions}

The best method of weed control varied with the crop grown. While mechanical weeding is beneficial in reducing weed populations it may also cause damage to the crop and therefore reduce yield. This work does not separate these two effects and therefore shows only the net effect of mechanical weeding on crop DM and yield. Future experiments should include a weed free control.

\section{ACKNOWLEDGEMENTS}

We thank Sean Bithell and Matthew Buchan for helping with field work. Financial support was provided by the Agricultural and Marketing Research and Development Trust (AGMARDT) and a Lincoln University Doctoral Scholarship.

\section{REFERENCES}

Bowman, G. 1997: Steel in the field: A farmer's guide to weed management tools. Sustainable Agriculture Network, Maryland. 128 p.

Friesen, G.H. 1986: Effect of weed interference on yield and quality of flax seed oil. Can. J. Plant Sci. 66: 1037-1040.

Gruenhagen, R.D.; Nalewaja, J.D. 1969: Competition between flax and wild buckwheat. Weed Sci. 25: 380-384.

Lee, H.C. 1995: Non-chemical weed control in cereals. Brighton Crop Prot. Conf. Weeds: 1161-1170.

Muzik, T.J. 1970: Weed biology and control. McGraw-Hill Book Company, New York. Pp. 68-77.

Pullen, D.W.M.; Cowell, P.A. 1997: An evaluation of the performance of mechanical 
weeding mechanisms for use in high speed inter-row weeding of arable crops. $J$. Agric. Eng. Res. 67: 27-34.

Regehr, D.L. 1993: Integrated weed management in agronomic crops. Communications $4^{\text {th }}$ International I.F.O.A.M. Conf: : 17-22.

Snowdon, B.; Wratten, S. 2000: Kowhai Farm, Heinz Wattie's organic farm at Lincoln University - a commercial demonstration organic mixed cropping farm. NZIPIM Conf. Proc.: 19-22.

Stiefel, W.; Popay, A.I. 1990: Weed control in organic arable crops. Proc. $43^{\text {rd }}$ N.Z. Weed and Pest Control Conf: : 138-141.

Vangessel, M.J.; Wiles, L.J.; Schweizer, E.E.; Westra, P. 1995: Weed control efficacy and pinto bean (Phaseolus vulgaris) tolerance to early season mechanical weeding. Weed Technol. 9: 531-534.

Welsh, J.P.; Bulson, H.A.J.; Stopes, C.E.; Froud-Williams, R.J.; Murdoch, A.J. 1997: Mechanical weed control in organic winter wheat. Aspects Appl. Biol. 50: 375-384. 